Araştırma Makalesi | Research Article

Doi: $10.18795 / \mathrm{ma} .16828$

\title{
Kaplan ÜSTÜNER
}

\author{
Doç. Dr. | Assoc. Prof. Dr. \\ Harran Üniversitesi, Fen Edebiyat Fakültesi, Türk Dili ve Edebiyatı Bölümü, Şanlıurfa-Türkiye \\ Harran University, Faculty of Science and Letters, Department of Turkish Language and Literature, Sanliurfa-Turkey \\ kaplanustuner@yahoo.com
}

\section{ERZURUMLU ZİHNî’NIN BESMELE KONULU MESNEVISİ}

\begin{abstract}
Özet
İslam dininin kaynaklarında önemle yer alan ve her hayırlı işin başı olarak tekrarlanan besmele, klasik şiirimizde de bahsedilen konular arasındadır. Besmele, daha çok divanların önsözleri ile ilk beyitlerinde, "bismillah" redifli gazellerde ve mesnevilerin giriş bölümlerinde ele alınmıştır. Besmelenin, divanlarda müstakil ve hacimli olarak ele alındığı mesnevi sayısı ise çok azdır. Bunlardan biri de Erzurumlu Zihnî’nin Divanında bulunan mesnevisidir. Bu makalede, bir divan şairinin müstakil olarak yazdığı besmele konulu mesnevisi incelenmeye çalışıldı. Besmele hakkındaki genel bilgiler giriş bölümünde verildi. Mesnevi, şekil ve içerik açısından incelendi. Aruzun "fe'ilâtün fe 'ilâtün fe'ilün" kalıbıyla yazılan mesnevinin toplam beyit sayıs1 118'dir. "Dinî mesneviler" grubunda yer alan manzumede, bölümler kesin çizgilerle birbirinden ayrılmamıştır. Mesnevide besmele, çok çeşitli açılardan ele alınmış, değişik benzetmelere konu edilmiştir. Mesnevinin bütün beyitlerinin dil içi çevirisi yapılmıştır. Beyitlerin günümüz Türkçesine aktarılmasıyla okuyucunun mesnevi ile doğrudan iletişim kurması amaçlanmıştır.
\end{abstract}

Anahtar Kelimeler: Besmele, Erzurumlu Zihnî, Mesnevi.

\section{BASMALA THEMED MASNAVI BY ZIHNI OF ERZURUM}

\begin{abstract}
Basmala, thought to be the starting point for every good deed and have been importantly stated in Islamic religious sources, is among the topics that are also mentioned in our classical poems. Basmala has been mentioned mostly in the prefaces and first couplets of divans, odes with basmala repeated voice and prologues of masnavis. The number of masnavis in which Basmala has been studied self-contained and intensely is very few. Masnavi by Zihni of Erzurum is one of these few masnavis. In this article, it is aimed to analyze a self-contained written, Basmala themed masnavi of a divan poet. The general information about Basmala has been stated in the introduction. Masnavi has been analyzed in terms of form and content. The total number of couplets of the masnavi that was written in the pattern of "fe'ilatün fe'ilatün fe'ilün", is 118 . In the poem that is among the religious masnavis, the chapters are not separated from each other transparently. Basmala has been discussed in various perspectives and mentioned in different metaphors. Each couplet of the masnavi has been translated. By citing the couplets in modernday Turkish, it is aimed that readers can communicate with the masnavis directly.
\end{abstract}

Keywords: Basmala, Zihni of Erzurum, Masnavi. 


\section{GíRiş}

\section{Besmele (Bismillâhirrahmânirrahîm)}

Besmele, "Rahman ve Rahim olan Allah'ın adiyla" anlamina gelen "Bismillahirrahmanirrahim" ifadesinin adıdır. Türkçede "besmele çekmek" ve "bismillah demek" tabirleri besmeleyi okumak anlamına gelir. "Euzü besmele" ise "kovulmuş şeytanın şerrinden Allah'a sı̆̆ınırım” anlamındaki “euzübillâhi mineşşeytanirracim” cümlesiyle besmelenin ortak adıdır. Kur'ân'da Neml sûresinin 30. âyetinde geçmektedir (Yıldırım 1992: 529).

Besmelenin başındaki "bâ" edatı (be harfi), kulun yaratıcısından yardım isteyerek hep ona bağlı kalışı ifade eder. Arapça cümle yapısı itibariyle besmeleden önce "bâ"nın ilgili bulunduğu gizli bir fiil vardır. Bu, besmele ile başlanacak herhangi bir fiildir: "Bismillah diye başliyorum.", "Bismillah diye kalkıyorum.", "Bismillah diye hayvan kesiyorum.” gibi (Y1ldırım 1992: 529-530).

İslam'da dünya ve ahiretle ilgili önemli, hayırlı ve meşru işlere besmele ile başlamak önerilmiştir. Hz. Peygamber, bir hadisinde "Besmele ile başlanmayan her iş bereketsiz ve güdüktür." (Aclûnî, II, 174) buyurmuş; çeşitli işleri münasebetiyle besmele çekmiş ve besmeleyi tavsiye etmiştir. Ayrıca bazı ibadetlerde besmele çekmenin gerekli olduğu bilinmektedir. Bir Müslüman besmele çekmekle, "Nefsim veya başka bir varlık adına değil Allah adına, onun rızası için ve onun izniyle başlıyorum.” demek ister. Allah’ın Rahman ve Rahim isimlerinin tecelli etmesini beklediğini, dünya ve ahiret mutluluğunu istediğini, başladığı işe güç yetirebilmesi için gerekli olan gücün Allah tarafından ihsan edilmesini dilediğini ve kendisinin devamlı olarak onun yardımına ihtiyaç duyduğunu ifade etmiş olur (Gözübüyükzade 1977: 25-30; Yıldırım 1992: 530).

Müslümanların inanç, ibadet ve günlük hayatlarında önemli yer tutan besmele, İslam'ın bir sembolü, her iyiliğin anahtarı ve Allah'ın kullarına ihsanıdır. Dinde çok önemli bir yere sahip olan besmele, her hayırlı işten önce söylenen bir sözdür. Kul ile Allah arasında kurulan en güzel bağlardan biridir. Onu söyleyen kişi, işin başında kulluğunu 
göstermiş ve Rabbine güvendiğini bildirmiş demektir. Çünkü besmele, Hakk'a teslimiyetin ve güvenin bir ifadesidir.

Hacı Bektaş-1 Veli, tükenmez bir kuvvet olan besmelenin önemini şöyle anlatmıştır: “Dünyada âdettir ki bir kişinin çok fazla düşmanı olsa, ona gücü yetmese, o da gider büyük bir kişinin eteğini tutar. Düşmanından daha kuvvetli olmak için onun yanında hizmetli olur, düşmanını kahreder. Ey müminler! Görünmeyen bir düşmanınız vardır. Adı şeytandır. Bir de galip dostunuz vardır. Adı Rahman ve Rahim'dir. Rahman ve Rahim'i oku ki şeytanı kahretsin ve kovsun.” (Duran 2014: 31, 114)

\section{Besmele ve Hat}

Hat sanatında en çok tekrarlanan ve çeşitli şekillerde en fazla yazılan âyetlerin başında besmele gelmektedir. Besmelenin yazımına özen gösterilmesiyle ilgili Hz. Enes’ten gelen bir rivayette, "Bismillahirrahmanirrahimi özenerek güzel yazan kişiyi Allah affeder." buyurulması ile Hz. Ali’nin "Besmeleyi güzel yazan kişi affedilmiştir.” Sözü, hattatların bu konuda gereken itinayı göstermelerinin başlıca sebebi olmuştur (Derman vd. 1992: 532-534).

\section{Besmele ve Klasik Şiir}

Besmele Arap, Fars ve Türk edebiyatında ele alınmış bir konudur. Arap edebiyatında besmelenin çeşitli yönlerinden bahseden risale ve şerhler yazılmıştır (Gürgendereli 2010: 25). Fars edebiyatında Molla Câmî (ö. 1492), besmele hakkında 19 beyitlik müstakil bir kaside ve üç divanının başında besmele ile ilgili beyitler yazdığı gibi Tuhfetü'l-Esrâr adlı mesnevisinin giriş bölümünü de besmeleye ayırmıştır (Sevgi 1999: $1-50)$.

Türk edebiyatına tesiri bakımından önemli bir şair olan Molla Câmî’nin yazdığı manzumeler, besmele ile ilgili yazma konusunda divan şairlerini etkilemiştir (Uzun 1992: 538; Sevgi 1999: 1-2; Gürgendereli 2010: 25-26).

Klasik edebiyatımızda manzum ve mensur hemen bütün eserler besmele ile başlamaktadır. 
Divan önsözlerinin (dîbâce) manzum ve mensur kısımlarında besmeleden bahsetmek usulden sayılmıştır (Üzgör 1990: 10-23).

Divanlara mısra ya da en az bir beyitten oluşan besmele şiiri ile başlanmış ve “bismillah” redifli gazeller yazılmıştır (Efe 2014: 48-76).

Besmele ile ilgili beyit ve şiirlere özellikle mesnevilerde rastlanır. Türkçe mesnevilerin giriş bölümleri genellikle besmele manzumeleriyle başlar (Uzun 1992: 538-539). Besmele ile ilgili konuların ele alındığg bu manzumelerin beyit sayısı 1'den 122'ye kadar ulaşır. Bunlar arasında Yahya Bey'in Gülşen-i Envâr mesnevisinin giriş bölümü 122 beyitle ilk sırayı almaktadır. Diğer mesnevilerde ise bu sayı 78'in altındadır (Gürgendereli 2010: 35-36).

Klasik şiirimizde besmele, daha çok telmih ve iktibas yoluyla kullanılmıştır. Besmelenin imlâsından faziletine kadar çeşitli yönlerinden bahsedilen bu eserlerden mensur olanlarda didaktik, manzum olanlarda ise estetik yönünün ağır bastığı dikkat çeker (Uzun 1992: 538).

\section{ERZURUMLU ZİHNî'NİN BESMELE KONULU MESNEVISİ}

Divanların önsözleri ile ilk beyitlerinde, besmele redifli gazellerde ve mesnevilerin giriş bölümlerinde ele alınan veya yer verilen besmele, müstakil bir mesnevi olarak divanlarda kendine çok az yer bulabilmiştir. Bunlardan biri de Erzurumlu Zihnî'nin ${ }^{1}$ Divanında yer alan mesnevisidir. Aşağıda bir divan şairinin müstakil olarak yazdığı besmele mesnevisinin şekil ve muhteva yönünden incelenmesiyle konunun klasik şiirimizde nasıl ele alındığının ortaya konması amaçlanmıştır.

\footnotetext{
${ }^{1}$ Erzurumlu Zihnî’nin (ö. 1794-97) asıl adı Mustafa'dır. 18. yüzyılın başlarında dünyaya gelen şair uzun bir hayat sürmüştür. Tahsil hayatı ve mesleği hakkında bilgi bulunmamaktadır. Şiirlerinden hareketle şairin klasik medrese eğitimi aldığı söylenebilir. Bilinen tek eseri olan divanında 19 kaside, 13 kıta, 9 musammat, 4 mesnevi, 328 gazel ve 1 müstezat yer almaktadır. Zihnî, klasik şiir çizgisinde özellikle Nâbî ekolünün taşradaki bir takipçisidir. (Macit 2001: 3-20)
} 


\section{MESNEVİNIN ŞEKIIL ÖZELLIKLERİ}

\section{Vezin}

Mesnevi, aruzun remel bahrinin "fe‘ilâtün fe'ilâtün fe'ilün" kalıbıyla yazılmıştır. Bu kalıp, 18. yüzyılda en çok kullanılan mesnevi kalıbı olma özelliği taşıdığından (Kartal 2013: 83-93), mesnevinin devrin genel eğilimine uygun şekilde yazıldı̆̆ı söylenebilir. Vezin, manzumede bir mısrada (77-1) görülen aksama dışında başarılı bir şekilde kullanılmıştır.

\section{Beyit Sayısı}

Kendi aralarında kafiyeli beyitlerden oluşan mesnevilerde beyit sayısının kısıtlayıcı bir kurala bağlı olmadığı bilinmektedir. Edebiyatımızda iki beyitten başlayarak binlerce beyit süren mesneviler kaleme alınmıştır. Zihn̂̂’nin besmele övgüsünü konu alan mesnevisinin beyit sayısı $118^{\prime} \mathrm{dir}^{3}$. Bu sayı, giriş bölümlerinde besmeleden bahseden 123 mesnevinin 122'sinden fazladır. Sadece Yahya Bey'in Gülşen-i Envâr mesnevisinin giriş bölümü, Zihnî’nin söz konusu mesnevisinden daha hacimlidir.

Mesnevinin 61. ve 62. beyitleri Arapça olarak kalem alınmıştır. Ayrıca 98'le 99 ve 100’le 101 numaralı beyitler de anlamın kendi içlerinde tamamlanmadı̆̆ı; ancak birlikte değerlendirildiklerinde anlamca bir bütün oluşturdukları merhun beyitlerdir.

\section{Yazılış Amacı}

“Besmelenin sırlarının açılması ve insanlığa iletilmesi” dileği, mesnevinin ilk yazılış amacidir. (1)

Başka bir amaç, şairin öldükten sonra Allah'ın af ve merhametine kavuşabilme arzusudur. (118)

\footnotetext{
${ }^{2}$ Erzurumlu Zihnî’nin besmele konulu mesnevisi, Muhsin Macit tarafindan hazırlanan divanda birinci sirada (Macit 2001: 107-116) yer almaktadır.

3 Divanda mesnevinin beyit sayısının 122 olarak görünmesi, rakamların yanlış dizilmesinden kaynaklanmış olmalıdır. Zira divanın transkripsiyonlu metninde de yazma nüshasında da mesnevi, toplam 118 beyittir.

${ }^{4}$ Parantez içindeki rakamlar, söz konusu beyitlerin metin ve dil içi çevirisini verdiğimiz mesnevideki numaralarını belirtmektedir.
} 
Çocuğun muhatap alınarak düşüncenin herkese ulaştırılma isteği ise mesnevinin diğer bir yazılma sebebi olarak dikkat çekmektedir $(101,109)$.

\section{Tertip Özelliği}

"Mesnevi tarzında besmele övgüsü" (Na't-1 Besmele Be-Siyâk-1 Mesnevî) başlıklı manzume, okuyucuya bilgi vermek, onu eğitmek ve yetiştirmek amacı taşıyan "dinî mesneviler" grubuna girer.

Bilindiği gibi mesnevilerin tertibinde genel olarak giriş bölümü, konunun işlendiği bölüm ve bitiș bölümü olmak üzere üç ana bölüm bulunur. Zihn̂̂’nin mesnevisinde başlıklar bulunmadığı gibi bölümler de birbirinden kesin çizgilerle ayrılmaz.

Mesnevinin genel görünümü, beyit numaralarıyla birlikte aşağıda bir tablo halinde gösterilmiştir:

\begin{tabular}{|l|l|l|}
\hline İçerik & Beyit Numaraları & Beyit Sayısı \\
\hline Besmele & $1 .-19 ., 23 .-25$. & 22 \\
\hline Besmelenin harfleri & & \\
\hline "Be” harfi & 28. & 1 \\
\hline “Be” harfinin noktası & $29 .-31$. & 3 \\
\hline "Sin” harfi & $32 .-36$. & 5 \\
\hline "Mim” harfi & $37 .-39$. & 3 \\
\hline Allah & $44 .-45 ., 49 .-50 ., 67 .-76 ., 78 ., 91 .-$ & 28 \\
& $96 ., 102 .-108$. & \\
\hline $\begin{array}{l}\text { Rahman, Rahim, Rahmet ve } \\
\text { Rizık }\end{array}$ & $51 .-53 ., 80 .-90 ., 97 .-101 ., 66$. & 20 \\
\hline Öğ̈̈tler & $22 ., 26 .-27 ., 46 .-48 ., 54 .-57 ., 77 .$, & 13 \\
& $79 ., 109$. & \\
\hline Dua & $58 .-65 ., 110 .-118$. & 17 \\
\hline Şiir ve Şair & $20 .-21 ., 40 .-43$. & 6 \\
\hline
\end{tabular}

\section{MESNEVININ MUHTEVASI}

Zihnî’nin besmele konulu mesnevisinin muhtevası, yukarıda verilen tertip düzenine göre, beyit numaraları da parantez içinde verilerek değerlendirilmiştir. 


\section{Besmele}

Mesnevinin ilk mısraında besmele ile ihlâs birlikte anılır. Besmelenin ihlâs ve içtenlikle söylenmesi gerektiği vurgulanır. Zira besmeledeki sırların açılması, ancak "Hakk'ın rızasını gözetmek" demek olan ihlâs ile dile getirilince mümkün olabilir. (1)

Besmele, İlahi kelam olan Kur'ân'ın bir sırrıdır. Bu sırlar, ancak çok dikkat edilince anlaşılabilir. $(1,2)$

"Besmele ile başlanmayan her iş bereketsiz ve güdüktür." (Aclûnî, II, 174) hadisine telmihte bulunularak besmelesiz bütün iş, fiil ve hareketlerin sonuçsuz, hayırsız ve eksik kalacağına işaret edilir. (4)

Cümlenin başı besmeledir. "Cümle" hem gramer hem de "herkes, bütün" anlamıyla kullanılır. İnsan, sözün başında bismillah demelidir. Baş önemlidir. Canlı bir varlık olan insanın başı önemli olduğu gibi asker topluluğu olan ordunun başı yani komutan da o derece önemlidir. İnsan başsız olamayacağı gibi ordu da komutansız olamaz. Kur'ân'ın başı da besmeledir. Kur'ân besmele ile başlar. Demek besmele büyük bir öneme sahiptir. (2)

"Bütün nesne ve olaylara ilişkin İlâhî ilim ve takdirin kayıtlı bulunduğu kitap" (Yavuz 2003: 151) demek olan levh-i mahfûzun baş tacı besmeledir. Levh-i mahfûza ilk yazılan odur. Kalem, levh-i mahfûza en önce besmeleyi yazmıştır. (3)

Besmele, levh-i mahfûza kudret eliyle nakşedilmiş tuğra ve süslü bir hattır. (24)

Kur'ân'ın başında zikredilen besmele, sûrelerin altın tacı olarak düşünülür. (18)

Uzayda da geçerli olan besmelenin gök cisimleri arasında saygın bir yeri vardır. Bütün sema adeta besmele ile yank1lanır. (3)

Kalemin ilk yazdığı besmeledir. Kalem, yazmaya besmele ile başlamıştır. (5)

Varlıklar ordusunun her zaman en önde bulunan sancağı besmeledir. (5)

Kâinatın yaratılışının sebebi besmeledir. Dünyadaki işlerin takdiri de onun sayesindedir. İnsan, bu yücelik karşısında hayret etmekten ve "Allah Allah” demekten başka çıkar yol bulamaz. $(6,25)$ 
Levhaların başına ilk olarak besmele yazılır. Kâğıtların üstünde izzetle duran besmelenin bu duruşu onun kudretini gösterir. $(7,13)$

Besmele, her şeyden üstündür. Kimse ona bir an olsun "hayır" diyemez. (8)

Besmeleyi övmeye, sıfatlarını anlatmaya ve şöhretini dile getirmeye söz yetişmez. (9) Şair, besmeleyi bütün yönleriyle tam olarak hiçbir âlimin anlatamayacağını ifade eder. (43)

Besmele, hakikat bahçesinin süsü ve ışığıdır. (10)

Hikmet denizlerinin suyu ve incisi besmeledir. (10)

Sağlıkta, hastalıkta ve çeşitli âfetlerde başvurulacak ilk söz besmeledir. (11)

Besmele, zorlukların çözüm yolu ve işe başlama sebebidir. Beyitte "okuma yaşına gelmiş çocukların, yapılan bir merasim ve duadan sonra hocanın önünde ilk olarak besmele çekmesini, bir başka deyişle okumaya başlamasını ifade eden" "bed'-i besmele" törenlerine de (Uzun 1992: 540) işaret vardır. (12)

Besmele, kitaplarda ilk olarak yazılan dîbâce/önsöz gibidir. (13)

Her iş için tükenmez bir güç olan besmele, işlerin hayırla tamamlanmasına sebep teşkil eder. (14)

İhsan ve lütuf kaynağı olan besmelenin anıldığı bir yerde Allah'ın iyiliği konusunda herhangi bir şüpheye yer kalmaz. Besmelenin Hakk’ın rahmeti konusundaki şüpheleri giderme işlevi vardır. (15)

Besmele, bütün olgunlukları bünyesinde taşıyan Kur'ân bahçesinin hoş kokulu ve zarif görüntülü sümbül çiçeğidir. (16)

Besmele, güzelliğin âşı̆̆ı bir bülbül gibidir. (16)

Cennet kapılarının açılma sebebi besmeledir. (17)

Besmele, eşyanın güvenle korunduğu bir mahzen gibidir. Allah'ın adını anan ve onun adıyla hareket eden kişi kendini güvende hisseder. (17) 
Besmele, “Hakk'ın katından doğrudan doğruya gelen bilgi” (Üstüner 2014: 210) demek olan ledün ilmi denizinin dalgalarıdır. (18)

Besmelenin zikredilmesi ve anlamının düşünülmesiyle kalpler nurlanır. (19)

Besmelenin kullanım alanının genişliğinin anlaşılmasıyla dimağlar amber gibi güzel kokar. (19)

İnci ve elmas gibi kıymetli taşlardan dizilip terkip edilen besmelenin gerçek değerinin anlaşılabilmesi için gözlerin dört açılması gerekir. (23)

Besmelenin, söz konusu mesnevide ilişkili bulunduğu kavram ve unsurları, aşağıda tablo halinde gösterilmiştir:

\begin{tabular}{|c|}
\hline Besmelenin Mesnevideki Anlam Çerçevesi \\
\hline ihlâs ile söylenmesi \\
\hline râz-ı kelâmullâh \\
\hline sırlarının dikkatle görünmesi \\
\hline cümlenin serdârı \\
\hline levh-i mahfûzun tâc-ı seri \\
\hline levh-i mahfûza tuğrâ olması \\
\hline âsmânın mu'teberi \\
\hline ef'âl, sükûn ve harekâtın besmelesiz ebter olması \\
\hline evvel-i ketb-i kalem \\
\hline ceyş-i eşyâya 'alem \\
\hline zuhûrâta sebeb \\
\hline kimsenin besmeleye bir an olsun "lâ" diyememesi \\
\hline her şeyden a'lâ \\
\hline midhat ve vasfina imkân olmaması \\
\hline şânını anlatmaya pâyân yok \\
\hline sebeb-i slhhat-i ebrâz \\
\hline merca'-ı zât ile a'râz \\
\hline sebeb-i hall-i müşâkil \\
\hline bâ'is-i bed'-i mu 'âmil \\
\hline levha satırlarına pîşvâ \\
\hline levha umûruna dîbâce \\
\hline ef'âle mü'eddî̀-i tamâm olması \\
\hline her işin besmeleyele istihkâm bulması \\
\hline
\end{tabular}




\begin{tabular}{|l|}
\hline cevherden terkîb olması \\
\hline gevherden tertîb olması \\
\hline dest-i kudretle yazılmış hat-l zîbâ \\
\hline sünbül-i bâğ-l kemâl \\
\hline bülbül-i hüsn-i cemâl \\
\hline sebeb-i feth-i der-i cennet \\
\hline mahzen-i kâle-i emniyyet \\
\hline süver-i mushafin altın tâcl \\
\hline ebhur-l 'ilm-i ledün emvâcı \\
\hline zikr ve fikriyle kalplerin nurlanması \\
\hline fehm-i şânıla dimâğın 'anber olması \\
\hline besmelenin rütbesini ta 'rîf ve tavsife haddin olmaması \\
\hline 'izzet \\
\hline rif'at \\
\hline Kudret \\
\hline 'izem \\
\hline Güher \\
\hline Kadr \\
\hline İhsân \\
\hline
\end{tabular}

\section{Besmelenin Harfleri}

Mesnevide besmelenin harfleri ile ilgili değerlendirmeler aşağıdaki gibidir:

\section{"Be"harfi ve noktasl}

Kur'ân'ın özünün Fatiha sûresinde, onun özünün besmelede, besmelenin özünün "be” harfinde ve onun özünün de "be" harfinin altındaki noktada bulunduğu, bu yüzden "be" 
harfinin insan nevinin suretini açıkladığı rivayet edilmiştir (Çelebioğlu 1998: 527). Mesnevide besmelenin " $b$ " harfi, yücelik burcu ve hakikat feleklerinin güneşine benzetilir. (28)

İmkân/varlıklar dairesi olarak düşünülen besmelenin "b" harfinin noktası, ihsan ve lütuf doludur. (29)

İnsanlar, "be" harfinin noktasındaki gerçek manayı anlayamaz ve hataya düşerler. (30)

Felek, sidre ve yüce arş, "be” harfinin noktasından görünür kılınmıştır. (31)

"Sin"harfi

Besmelenin "sin" harfi, vahdet bahçesinin sümbül çiçeği, ihsan ve lütuf iyiliğinin hazinesidir. (32)

"Sin" harfinde hakikat ve incelikler çoktur. (33)

Kılıca benzetilen "sin” harfi, düşmanın başına kılıç çekmiş, dik başlı ve inatçı kişileri de hor görmüştür. (34)

"Sin" harfi, doğru yoldan sapan ülkenin yoluna set olur ve istikamette süreklilik gösterir. (35)

Değeri ve şöhreti çok yüksek olduğu için "sin” harfi ne kadar övülse yerindedir. (36)

"Mim” harfi

Besmelenin “mim” harfi, Hakk’1n iyilik ve lütuf hazinesidir. (37)

Hikmet bahçesinin goncası "mim" harfidir. İlahi kudret tarafından ona feyiz verilir. (38)

“Mim” harfinin halkası, âlemin halkası olarak hayal edilir. (39)

\section{Allah}

Allah, kendisinden başka ilah bulunmayan; ilmi, iradesi, kudreti, azameti ve yaratması sonsuz olan hakiki mabûdun zat ismidir. O eşi, benzeri ve ortağı olmayan, doğurmamış, doğrulmamış, hiçbir şeyin kendisine denk olmadığı mutlak varlığın özel adıdır. Kendisinden başka hiçbir varlık bu adı alamaz. Allah isminin manasına nüfûz etmeye 
çalışan insan şu gerçeği anlayacaktır: Ondan başka yaratıcı yoktur. Kula düşen onun varlığına, birliğine inanmak ve ibadet etmektir (Efe 2014: 8-10). Zihnî, besmelede yer alan "Allah" lafzının gönül dünyasına yansıyan ince manalarını şu şekilde dile getirir: (44)

Bunun için şair önce akıl kilidini eline alır. Akılcı bir yaklaşım sergiler. Konuyla ilgili aklî ve naklî delilleri ortaya kor. (45)

Allah lafzı çok değerli ve eşsiz bir inciye benzer. İlahî isimleri kale gibi kuşatıcı ve kapsayıcıdır. Bin bir isim Allah lafzından kaynaklanır. Bütün sırlar bu isimde gizlenmiştir. $(49,50)$

Bedenlerin ve ruhların gıdasını yaratıp veren (Râzık), her şeye gücü yeten, kudretli (Kâdir), daima affeden, tekrarlanan günahları bağışlayan (Gaffâr), varlığını ve birliğini belgeleyen birçok delilin bulunması açısından âşikâr olan (Zâhir), zatının görülmesi ve mahiyetinin bilinmesi açısından gizli olan (Bâtın), kusur ve günahları örten (Settâr) Allah'tır. (67)

Ulûhiyette, tasarrufta, rubûbiyette ve hakikatte sadece Allah vardır, ondan başkası yoktur. (68)

Allah'ın ne ortağı, ne benzeri, ne de eşi vardır; ne komutanı ne de ordusu vardır. Zatı birdir. (69)

Emir ve eylemlerde en üstün Allah’tır, her şey sonunda ona dönecektir. (70)

Sürekliliğinin şahidi insanlardır. Ezeli ve ebedi oluşunun/kayyûmiyetin göstergesi ise kâinattır. (71)

Zatının ezeli/öncesiz ve ebedi/sonrasız oluşuna şahit, yaratılan her şeydir. (72)

İnsan; yer, gök, arş, ay, güneş ve havaya dikkatle bakmalıdır. (73)

Gündüz ile gecenin düzenli bir şekilde birbirini takip edişini, sayısız gök cismi ve dağları düşünmelidir. (74) 
Her şeyi takdirine uygun bir şekilde yaratan (Hâlık) ve yarattıklarının rızkını veren (Râzık) odur. (75)

İnsan, aklî ve naklî delillerle Allah'ın varlığı ve birliğini ispatlamaya çalışmalıdır. Delilleriyle inandıktan sonra imanını en üst dereceye eriştirmelidir. (76)

Ortaya konan bu kuvvetli deliller, Allah'ın eşi ve ortağı olmadığını ispat ederler. (78)

Tevhit konusunda -varsa- şüpheler bırakılmalı, "Allah’tan başka ilah yoktur.” diyerek hata ve kusurlar itiraf edilmelidir. (91)

Hakk'ın birliğgi konusunda Kur'ân'dan delil getirilir ve iktibas yapılır: "De ki: O Allah’tır, tektir.” (İhlâs, 112/1) (92)

Allah, her şeye gücü yeten, kudretli bir sultandır. Azamet sahibidir. Zâhir'dir. (93)

O, bir kişiyi padişah iken köle, köleyi de görkemli bir padişah yapabilir. (94)

Allah, insanların kimini âlim kimini de üstün bir komutan yapmıştır. (95)

Bir zerre dahi Allah'ın emrinden hariç değildir. Aklı olan, bu gerçeği anlamaya çalışır. (96)

Allah’ın büyüklüğü karşısında hiçbir şey varlık davasına kalkışamaz. Zaman, mekân ve eşya onun yüceliğine kıyasla yok sayılır. (102)

Ceberût "Allah'ın zâtı", melekût "Allah'ın ezelî sıfatlarını" yahut "kâinat üzerindeki İlâhî güç ve hâkimiyeti" ifade eder. Ceberût âleminde Hak, halk için neyi irade ve takdir etmişse o olur (Gündüz 1993: 193-194; Aydın 2014: 45-47).Varlıklar, Allah’ın ceberûtunda zelîl, melekûtunda ise iki kat olmuştur. (103)

Allah, kudretiyle tüm varlıkları idaresi altına almıştır. (104)

Bütün âlem o kudretin bir sarayıdır. Tüm dünya ise hikmetini anlamayan âcizlerle doludur. (105)

Son noktada aklın kanunları geçerliliğini yitirir. Kalbin tasdiki gerekir. (106) 
Akıllı geçinenler bu yolda yaya kalır. Şüpheden uzak sağlam bir inanca sahip olmalıdır. (107)

İnsan,“Allah’tan başkasına ibadet etmeyin.” (Âl-i İmrân, 3/64) hakikatine yapışmalı ve Hak’tan başkasına gönül vermemelidir. (108)

\section{Rahman, Rahim, Rahmet ve Rızık}

"Esirgeyen bağışlayan, lütuf, merhamet ve ihsanını eksiltmeyen” anlamındaki Rahman ve Rahim isimleri, ilâhî rahmetin bütün âlemi kucakladığını ifade eder. Bu isimler ve ifade ettikleri rahmet ve rızık hakikatleri, mesnevide aşağıdaki şekilde değerlendirilmiştir:

Allah, lütfunu Rahman ve Rahim isimleri ile müjdelemiştir. (51)

Besmelede yüce isimlerden Rahman ve Rahim birlikte kullanılmıştır. (52)

Bu isimler, Hakk'ın rahmetine delil ve bereketine kefil olmuştur. (53)

İnsanlar, ibadetlerini terk ederek rızık için koşuşturup durmamalıdır. Çünkü Allah, rızka kefildir. Beyitte, "Nice canlılar vardır ki, rızıklarını taşımazlar (yiyecek biriktirmezler). Onları da sizi de Allah rızıklandırır." (Ankebut, 29/60) ve "Şüphesiz Allah rızık verendir.” (Zâriyât, 51/58) âyetlerine telmih yapılır. (80)

Şair, Enes bin Malik’ten naklen bir hadis aktarır (81): Yer gök, gece gündüz kısaca dünya henüz yaratılmadan önce, Allah yarattıklarının rızıklarını bildirmiştir. Beyitte geçen "iki bin yıl akdem” ifadesi "Ruhlar bedenlerinden iki bin yıl önce yaratılmıştır!" (Deylemî, Müsned, II, 187-188) hadisine göndermedir. İnsanların rızıkları, vücut elbisesini giymeden ruhlar yaratıldıkları vakit kararlaştırılmıştır. (82-84)

$\mathrm{Bu}$ konu üzerinde dikkatle durmalı ve ibadetlerin terk edilerek rızık için yapılan koşuşturmalara bakıp utanılmalıdır. (85)

Rızkın Allah tarafından verildiğine hadisten sonra şu âyet delil olarak gösterilir: "Biz taksim ettik/paylaştırdık." (Zuhruf, 43/32). İnsan, bu İlâhî fermandan zevk almalıdır. (86-87) 
Allah'ın rızık konusundaki -kimi insana az kimine çok vermesi gibi- hikmetinden sual olunmaz. Bir şeyi az ya da çok vermesi yahut hiç vermemesi hikmetinin gereğidir. Onun hikmetini kabul etmemek kişiyi küçük düşürür. Allah'ın her şeye gücü yeter. Onun kudretini inkâr edenin eline, ağlayıp sızlamaktan başka bir şey geçmez. (88)

İnsan, yaşadığı sürece Allah'ın emrettiklerini yapıp yasaklarından kaçınmakla görevlidir. (89)

Kulun Allah'a teslim olması ve ona itaat etmesi gerekir. (90)

Allah'ın iyilik ve lütuf sofrasından küçük büyük herkes yararlanır. (97)

Hakk'ın cömertlik sofrası çok geniştir. Onun sofrasının genişliğine kıyasla, dünyanın hacmi bir tabak kadar bile değildir. (98-99)

Yeryüzündeki bütün denizler, Allah'ın iyilik ve rahmet denizine kıyasla bir içim su dahi değildir. (100-101)

Karşıllk beklemeden bol bol veren Vehhâb'a hamd, iyilik ve lütuflarda bulunan Mennân'a şükretmek gerekir. (66)

\section{Öğütler}

Mesnevide hitap yollu anlatım tarzı ile insanlara çeşitli öğ̈̈tler verilir:

"Ey dânâ" hitabıyla bilgiçlik taslayanlara seslenilir. Gönül gözünü açmak gerekir. Besmelenin hakiki manasını anlayıp gerçek kıymet ve derecesini takdir etmelidir. (22)

Besmelenin ifade ettiği hakikatleri anlayan Allah’tan başka her şeyi unutur. (26)

"Ey hıredsiz" diye besmelenin değerini anlamayan akılsızlara seslenilir. Kalp ayna gibi temizlenmelidir. (27)

Besmelenin yüksek derecesi, ancak hakikati idrak eden ve güzellikten zevk alanlara anlat1labilir. (46)

Ey selim yaradılışlı! Anlatılanlardan ders almalı ve doğru yoldan sapmamalıdır. (47)

Ârif olmalı, kemal sıfatlar kazanmalı ve Hakk'a dua etmelidir. (48) 
Gözden gaflet perdesini kaldırmalıdır. Perdeyi kaldırınca her yüzden Hakk'ın tecelli ettiği görünecektir. (54)

Bilgi, insanı eşsiz bir varlık haline getirir. Bilen kişi konuşur. (55)

İşlerinin uygunluğu için gerekli tedbirleri alan bilgili insanın sözü herkesi etkiler. (56)

Bilen kişi, sonunda bütün hedef, istek ve arzularına ulaşır. (57)

İnsanlar arasında bozgunculuk yapmamalıdır. (77)

Sadece dünya işleriyle uğraşıp gönle zarar vermemelidir. Kişi, her gördüğü şeyi istememelidir. (79)

İnsan, istikametten ayrılmayıp doğrulukla çalışmalıdır ki sonuçta üzülmesin. (109)

\section{Dua}

Mesnevinin hem ortasında hem de sonunda Allah'a dua edilir. İki beyti (61. ve 62.) Arapça olarak yazılan bu bölümde Zihnî Hakk'a şöyle yalvarıp yakarır:

Ey Allah'ım! Bana yardım et. Medet! Düşüncemi, incelikleri görüp anlayabilen bir duruma getir ve sürekli k1l. (58)

Dilimi anlamın toplandığg yer, kalbimi gizemli mekân yap. (59)

Ey Zâhir ve Bâtın olan yüce Allah! İstek ve gayem sadece sensin! (60)

Hamd sana, şükür sanadır. Minnet senin, ikram ve bağış senindir. (61)

Sen dirisin, ezelî ve ebedîsin. Ey arzu ve ihtiyaçları sebebiyle herkesin yöneldiği ulular ulusu bir müstağni olan Samed! Sen fiilen var olan, mevcudiyeti ve ulûhiyeti gerçek olan Hak'sin, bir tek Ahad'sin. (62)

Ey ululuk sahibi (Celâl) Allah! Beni sevindir, irfan şarabı ile kendimden geçir. (63)

Söz ve davranışlarımı düzelt! Bana sırlarını açıkla! (64)

Ey iyilik ve lütuflarda bulunan Allah'ım! Beni affet ve şanına yakışır bir kul haline getir. (65)

Ey Allah'1m! Bana ihsanda bulun. Merhametinle isteklerime kavuştur. (110) 
Annemi ve babamı sevindir. Onları cehennem ve diğer korkulardan kurtar. (111)

Yerlerini cennet eyle, gazabınla cehennem ateşi yapma. (112)

Kâinatın sultanı Hz. Muhammed ve onun sahabeleri hürmetine... Arş, kürsü ve cömertliğinin hürmetine... Kalem ve levhanın ruhu hürmetine... Yüce kitabımız hürmetine... Ey bağış kaynağı! Ey varlıklara cömert olan! Ölüm anımı, can çekişimi kolaylaştır. Yerimi cennet bahçelerinden bir bahçe eyle. (113-116)

Gam çeken Zihnî’yi inletme, cehennem korkusu ile ağlatma! (117)

Ey ihsan sahibi Rabbim! Sana hediyem bu mesnevidir. Beni, af ve merhamet ettiklerinin arasinda eyle. (118)

\section{Şiir ve Şair}

Zihnî, mesnevisini hem farklı bir tarz hem de çeşitli konulara değinen bir manzume olarak değerlendirmiştir. (21) Mesnevi, gerçekten de besmeleyi çeşitli yönleriyle ele alan müstakil bir manzume olması sebebiyle özgündür.

Şair, besmelenin derecelerini hiçbir âlimin tam olarak anlatamayacağını ve "zerre" olan kendisinin de gönlüne doğan bazı hakikatleri dile getirdiğini söyler. (20, 43-44)

Şairlik yaratılışını bülbüle benzeten Zihnî, gül olarak hayal ettiği besmele karşısında sessiz kalamamıştır. $(40,42)$ Şair, mesnevisinin insanlığın düşünce ve gönül dünyasını aydınlattığ inancındadır. (41)

\section{SONUÇ}

Erzurumlu Zihnî'nin Divanında yer alan besmele konulu müstakil mesnevisi, şekil ve muhteva yönünden incelenerek klasik şiirin konuya yaklaşımı örnekle gösterilmiştir. Bu çalışma ile divanlarda incelemeye değer özgün manzumelerin bulunduğu örneklendirilmiştir. 


\title{
METIN VE DÍL İÇi ÇEVIRIsisi ${ }^{5}$
}

\author{
Na't-ı Besmele Be-Siyâk-ı Mesnevî \\ [Mesnevi tarzında besmele övgüsü] [Fe 'ilâtün fe 'ilâtün fe 'ilün]
}

1. Deyip ihlâs ile bismillâhı

Açalım râz-1 kelâmullâhı

[Bismillahı ihlâs ile söyleyip Kur'ân'ın sırrını açalım.]

2. Cümlenin besmeledir serdârı

Dikkat etsen görünür esrârı

[Cümlenin başı besmeledir. Sırları, dikkat edilince görünür.]

3. Levh-i mahfûzun odur tâc-1 seri

Cümle âsmânın odur mu'teberi

[Levh-i mahfûzun baş tacı ve bütün gökyüzünün itibarlı olanı besmeledir.]

4. Ansiz ef'âl ü sükûn u harekât

Cümle ebter olur anlar bi'z-zât

[Onsuz başlanılan bütün iş, eylem, durum ve hareketler faydasız olur.]

5. Evvel-i ketb-i kalem besmeledir

Ceyş-i eşyâya 'alem besmeledir

[Kalemin ilk yazdı̆̆ besmeledir. Eşya ordusuna sancak besmeledir.]

6. Bu zuhûrâta sebeb bismillâh

Bu ne 'izzet durur Allâh Allâh

[Bu evrenin yaratılışına, varlıkların ortaya çıkışına sebep bismillahtır. Allah Allah! Bu ne büyüklüktür!]

7. Levhin üstünde durur 'izzet ile

'Alem-i kudretidir rif'at ile

[Levhanın üstünde izzetle durur. Bu yücelik ile duruşu, gücünün göstergesidir.]

\footnotetext{
${ }^{5}$ Mesnevinin bilimsel neşri yapıldığı için metinde transkripsiyon alfabesi kullanmadık. Okuma kolaylığı sağlayacağı düşüncesiyle de ünlüleri günümüz imlâsına uyarladık. Dil içi çevirisini yaparken, mümkün olduğunca şairin metinde kastettiği anlamı yakalamaya gayret gösterdik. Divanda mesnevinin farklı şekilde tespit edilen birkaç kelimesi, yazının amacı dışında olduğundan söz konusu edilmedi. Bu vesileyle, Erzurumlu Zihnî divanını hazırlayan ve mesnevinin yazma nüshasının ilgili sayfalarını elektronik ortamda tarafımıza gönderme nezaketinde bulunan değerli edebiyat araştırmacısı Prof. Dr. Muhsin Macit'e teşekkürlerimi sunarım.
} 
8. Ana kimse diyemez bir dem lâ Olduğıyçün dükelinden a'lâ

[Her şeyden üstün olduğu için kimse ona bir an dahi "hayır” diyemez.]

9. Midhat ü vasfına imkân yokdur

Şânını nakl ile pâyân yokdur

[Övme ve sıfatlarını dile getirmeye imkân yoktur. Şanı ise anlatmakla bitmez.]

10. Bâğ-1 tahkîkin odur zîb ü feri

Ebhur-1 hikmetin âb1 güheri

[Hakikat bahçesinin süsü ve ışığı ile hikmet denizlerinin suyu ve incisi odur.]

11. Sebeb-i sihhat-i ebrâz oldur

Merca'-1 zât ile a'râz oldur

[Mevcut să̆lı̆̆ın sebebi odur. Hastallk ve musibetlerde de doğrudan doğruya başvurulacak makam odur.]

12. Sebeb-i hall-i müşâkildir ol

Bâ'is-i bed'-i mu'âmildir ol

[O, benzer zorlukların çözüm yolu ve çalışanların işe başlama sebebidir.]

13. Pîşvâ oldu sutûr-1 levha

Oldu dîbâce umûr-1 levha

[Kâğıttaki satırların başına ve kitaplara önsöz mahiyetinde ilk o yazıldı.]

14. Oldu ef'âle mü'eddî-i tamâm

Bulur anınla her iş istihkâm

[İşlerin tamamlanmasına sebep oldu. Her iş onunla güç ve sağlamlık kazanır.]

15. Kanda yazılsa anılsa şânı

Alınır şâ'ibe-i-i ihsânı

[Şöhreti nerede anılsa ve yazllsa, ihsan konusundaki şüpheler giderilir.]

16. Sünbül-i bâğ-1 kemâl olmuşdur

Bülbül-i hüsn-i cemâl olmuşdur

[Olgunluk bahçesinin sümbülü ve güzel yüzün bülbülü olmuştur.]

17. Sebeb-i feth-i der-i cennetdir

Mahzen-i kâle-i emniyyetdir

[Cennet kapısının açılma sebebidir. Eşyaların güvenle korunduğu mahzendir.] 
18. Süver-i mushafin altın tâcı Ebhur-1 'ilm-i ledün emvâc1

[Kur'ân sûrelerinin altın tacı, ledün ilmi denizlerinin dalgalarıdır.]

19. Zikr ü fikriyle kulûb enverdir Fehm-i şânıyla dimâğ 'anberdir [(Besmeleyi) zikredip anlamını düşünmekle kalpler daha nurlanır. Ününün anlaşılmasıla da dimağ amber gibi güzel kokar.]

20. Zerrenin haddi mi var tavsîfe Rütbe-i besmeleyi ta'rîfe [Besmelenin üstün mertebelerini anlatmaya (benim gibi) bir zerrenin gücü mü yeter?]

21. Sana bir gûne suhan yâd edelim Bir niçe vâk1'a bünyâd edelim [Sana çeşitli sözler nakledeyim ve birçok konunun esasını anlatayım.]

22. Dîde-i bâtınını eyle güşâ 'İzem ü kadrini gör ey dânâ [Ey bilgiç! Gönül gözünü aç; (besmelenin) büyüklük, klymet ve derecesini gör.]

23. Bak ne cevherden olunmuş terkîb Gör ne gevherden olunmuş tertîb [Bak! Nasıl bir cevherden birleştirilmiş. Gör! Nasıl bir inciden dizilmiş.]

24. Levh-i mahfûza o bir tuğrâdır Dest-i kudretle hat-1 zîbâdır [O, levh-i mahfüza bir tuğra ve kudret eliyle nakşedilmişs süslü bir hattır.]

25. Buldu takdîr-i umûr-1 'âlem Bâ'is-i zâtı ile nakş u rakam [Dünya işlerinin takdiri, besmele sebebiyle yazllıp çizildi.]

26. Sifat-1 besmeleyi gûş etdin Fikr-i ağyârı ferâmûş etdin [Besmelenin sıfatlarını dinledin. Masiva düşüncesini unuttun.]

27. Kalbini âyîneveș sâf eyle Ey hiredsiz yeter insâf eyle [Ey akılsız! Yeter! Insaf et! Kalbini ayna gibi temizle!] 
28. Bâsıdır burc-1 şerâfet mihri Ya'nî eflâk-i hakîkat mihri [Yücelik burcunun yani hakikat feleklerinin güneşi besmelenin "be” harfidir.]

29. Noktası dâ'ire-i imkândır Nokta-i kün gibi pür-ihsândır ["Be" harfinin noktası, imkân dairesidir; "kün/ol" kelimesindeki "nun" harfinin noktasl gibi ihsan doludur.]

30. Noktasın anlayamaz nev'-i beșer

Fehm-i şânında kusûr eylerler

[İnsanlar, "be" harfinin noktasındaki gizemi anlayamaz ve ününü idrakte kusur ederler.]

31. Felek ü sidre vü 'arş-1 a'lâ

Nokta-i besmeleden oldu nümâ

[Felek, sidre ve yüce arş besmelenin "be" harfindeki noktasından göründü.]

32. Sînidir sünbül-i bâğ-1 vahdet

Mahzen-i lutf-1 nevâl u 'azamet

[Vahdet bahçesinin sümbülü, ululuk ve bă̆ış iyiliğinin mahzeni besmelenin "sin”" harfidir.]

33. Sırr-1 zâtında hakâyık çokdur

Hadd-i zâtında dekâyık çokdur

[Zatının sır oluşunda birçok hakikat vardır. Gerçekte bu konuda incelikler çoktur.]

34. Ser-i a'dâya çeküpdür şemşîr

Niçe ser-keşleri eyler tahkîr

[Sin harfi, düşmanın başına kılıç çekmiştir. Dik başlı ve inatçı kişileri hor görür.]

35. Reh-i iklîm-i dalâla seddir İstikâmetde hemân sermeddir

[Doğru yoldan sapan ülkenin yoluna settir. İstikamette ise süreklilik gösterir.]

36. Şânı çün kadri gibi a'lâdır

Medh olunsa ne kadar evlâdır

[Ne kadar övülse yerindedir. Çünkü şöhreti gibi değeri de çok yükssektir.]

37. Mîmidir mahzen-i lutf-1 Mevlâ

Ya'nî gencîne-i eltâf-1 Hudâ

[Mevlâ'nın iyilik mahzeni yani Allah'ın lütuf hazinesi besmelenin "mim” harfindedir.] 
38. Gonce-i gülşen-i hikmetdendir Ana bu feyz ise kudretdendir

["Mim” harfi, hikmet gül bahçesinin goncalarından biridir. Ona verilen bu feyiz ise (Ilahi) kudrettendir.]

39. Halkası halka-i 'âlemdir anın Hâleveş dâ'ire-i imkânın

[Mim harfinin halkası, imkân dairesinin ay ă̆ılı gibi âlemin halkasıdır.]

40. Bülbül-i tab'1mı bîdâr etdi Reh-i hayretde sebükbâr etdi

[Şairlik yaratılışımın bülbülünü uyandırdı. Hayret yolunda yükümü hafifletti.]

41. Verdi endîşeme fikri eşvâk Hâne-i kalbimi kıldı işrâk

[Fikri, düşünceme coşkunluk verdi; gönül dünyamı aydınlattı.]

42. Olsa bir bâğda gül hem bülbül Nice ol câyda olmaz kulkul [Bir bahçede gül ile bülbül olsa orada nasıl ses olmaz?]

43. Ben değil olsa niçe nâdiredân Edemez kadrini bir dürlü 'ayân [Değil ben çok değerli âlimler de olsa, onun gerçek değerini tam olarak açıklayamaz.]

44. Gelelim lafza-i bâ-iclâle Bakalım nükte-i mâ-fi'l-bâle

[Yüce “Allah”ın lafzına gelelim. Onun gönle doğan ince anlamlarına bakalım.]

45. Alalım deste kilîd-i 'aklı Açalım mahzen-i 'akl u nakli [Akıl kilidini ele alalım. Akıl ve nakil mahzenini açalım.]

46. Ey harîdâr-1 hakîkat gûş et Ey hevesnâk-i letâfet gûş et [Ey hakikat alıcısı! Ey güzellik heveslisi! Dinle!]

47. Hisse al kıssadan ey tab“-1 selîm I'tisâf etme sakın olma sakîm [Ey sağlam yaradılışlı! Kıssadan hisse al. Sakın! Doğru yoldan sapma! Hasta olma!] 
48. 'Ârif ol kesb-i kemâlât eyle Cânib-i Hakk'a münâcât eyle

[Ârif ol! Olgunluklar kazan. Hakk'a yönel ve dua et.]

49. Lafzatu'llâhı dür-i yek-tâdır Kal'aveş hâsıra-i esmâdır

[Allah lafzı eşsiz bir incidir. Kale gibi isimleri kuşatıcıdır.]

50. Bin bir esmâ olur andan mefhûm Anda esrâr olupdur mektûm

[Bin bir isim ondan anlaşılır. Bütün sırlar "Allah” sözünde gizlenmiştir.]

51. Sana tebşîr eder ey kalb-i selîm Lutf-1 Mevlâ ${ }^{6}$ ile Rahmân u Rahîm

[Ey selim kalp! Rahman ve Rahim isimleri ile Mevla lutfunu sana müjdeler.]

52. Muttasıl hey'et-i Rahmân u Rahîm Ya'nî esmâ-i cedîrü’t-ta'zîm

[Yüceliğe uygun Rahman ve Rahim isimleri birlikte kullanılır.]

53. Rahmet-i Hakk'a güvâh olmuşlar Zâmin-i feyz-i İlâh olmuşlar

[Bu isimler, Hakk'ın rahmetine delil ve feyzine kefil olmuştur.]

54. Perde-i gafleti kaldır gözden Görüne nûr-1 $\operatorname{Hudâ}^{7}$ her yüzden

[Gözden gaflet perdesini kaldır. Her yüzden Hakk'ın nuru görünsün.]

55. Ma'rifet âdemi yek-tâ eyler

Hâsılı tûtî-i gûyâ eyler

[Marifet, insanı eşi benzeri olmayan bir varlık haline getirir; kısacası konuşan papağan yapar.]

56. Sühanı herkese te'sîr edip Vefk-i ef'âline tedbîr edip [(Bilgili insanın) sözü herkesi etkiler. Kişi, işlerinin uygunluğu için tedbir alır.]

\footnotetext{
${ }^{6}$ Yazma nüshada "Lutf u Mevlâ" şeklinde kayıtlıdır.

77 Yazma nüshada "Hüdâ" şeklinde kayıtlıdır.
} 
57. Kâm-1 dil-hâhına çün vâsıl olur Matlab u maksadına nâ'il olur

[Böylece gönlün arzularına kavuşur; istek ve amaçlarına erişir.]

58. Yâ İlâhî bana lutf eyle meded

Fikrimi eyle dakîk ü mümted

[Ey Allah'ım! Medet! Bana yardım et. Düşüncemi, incelikleri görüp anlayabilen bir duruma getir ve sürekli kal.]

59. Dilimi mesken-i ma‘nâ eyle Kalbimi cây-1 mu'ammâ eyle

[Dilimi anlamın toplandı̆̆ yer, kalbimi gizemli mekân yap.]

60. Matlabım maksadım ey hazret-i Hak

Sensin ey Zâhir ü Bâtın mutlak

[Ey Zâhir ve Bâtın olan yüce Allah! İstek ve gayem sadece sensin!]

61. Leke hamdu leke şükr ü senâ Leke minne leke fazl $u$ 'atâ

[Hamd sana, şükür sanadır. Minnet senin, ikram ve bağış senindir.]

62. Ente hayyün ezeliyyün ebedî Ente Hakkun Ahadün yâ Samedî

[Sen dirisin, ezelî ve ebedîsin. Ey hiçbir şeye muhtaç olmayan! Sen Hak’sın, birsin.]

63. Zü'l-Celâlâ beni mesrûr eyle Câm-1 'irfân ile mahmûr eyle

[Ey ululuk sahibi Allah! Beni sevindir, irfan şarabı ile kendimden geçir.]

64. Kavlimi fi'limi islâh edip Bana esrârını izâh edip

[Söz ve davranışlarımı düzelt! Bana sırlarını açıkla!]

65. Şânına lâyıkın et sultânım

Beni afveyle benim Mennân'ım

[Ey ihsanı bol Allah'ım! Beni affet. Beni, şanına yakışır bir kul haline getir.]

66. Hamd o Vehhâb-1 kesîrü'l-kereme

Şükr o Mennân-1 veliyyü'n-ni'ama

[Hamd, bağışı çok Vehhab'a; şükür, nimetlerin gerçek sahibi Mennan 'adır.] 
67. Râzık u Kâdir [ü] Gaffâr oldur Zâhir ü Bâtın u Settâr oldur

[Rızık veren, her şeye gücü yeten, bağışlayan, görünen, görünmeyip gizlenen ve kusurları örten Allah'tır.]

68. Yok tasarrufda ulûhiyyetde Yok hakîkatde rubûbiyyetde [Ulûhiyette, tasarrufta, rububiyette ve hakikatte ondan başkast yoktur.]

69. Ne şerîk ü ne misâl ü ne nazîr Bir durur zâtı ne mîr ü ne vezîr [Ne ortağı ne benzeri ne eşi vardır. Ne komutanı ne ordusu vardır. Allah 'ın zatı birdir.]

70. Cümle eşyâ ana râci'dirheb Emr ü ef'âlde oldur ağleb

[Bütün varlıklar sonunda ona dönecektir. Emir ve eylemlerde en üstün odur.]

71. Halkdır şâhid-i deymûmiyyet Kevndir mazhar-1 kayyûmiyyet

[Sürekliliğin tanığı insanlardır. Ezelî ve ebedî oluşun göstergesi varlıklar âlemidir.]

72. Ebedîdir ezelîdir zâtı Ana şâhid çü bu mahlûkâtı

[Allah'ın zatının öncesiz ve sonsuz oluşuna yaratılan bütün varlıklar tanıktır.]

73. 'Arş ile ferş ü semâya nazar et Mâh ile mihr ü hevâya nazar et [Yer, gök, arş, ay, güneş ve havaya dikkatle bak!]

74. Devr-i eyyâm u leyâli fikr et Bunca ecrâm u cibâli fikr et

[Gündüz ile gecenin dönüşü ve birbirini takip edişini; sayısız gök cismi ve dağları düşün!]

75. Cümlesin hazret-i Hak'dır Hâlık Cümleye hazret-i Hak'dır Râzık [Bütün varlıklarl yaratan ve onlara rızkını veren yüce Allah'tır.]

76. 'Akl u nakl ile çalış isbâta

Asl-1 tasdîki yetir gâyâta [Aklî ve naklî ilimlerle ispata çalış. Tasdikin aslını, inancın esasını son dereceye ulaştır.] 
77. Mâ'il-i hâ'itü'l-hâd olma

Râgıb-1 cânib-i ifsâd olma

[Çaylak kuşu gibi kafese meyletme! Bozgunculuk tarafina rağbet gösterme!]

78. Hakk'1 bilmekde seneddir bunlar

Bî-şerîk olduğun isbât eyler

[(Anlattığımız bu konular) Hakk'ı bilmekte kuvvetli delildir. Onun eşi ve ortağı olmadığını kanıtlar.]

79. Şugl ile kalma dil-âzâr olma

Gördügün şeye talebkâr olma

[Sadece dünya işleriyle uğraşma! Gönlünü incitme! Her gördüğün şeyi isteme!]

80. Rızkına hazret-i Hak'dır kâfil

Rızk için etme şitâb ey gâfil

[Ey gafil! Rızık için çok fazla koşuşturma! Allah senin rızkına kefildir.]

81. Çûn buyurdu Enes bin Mâlik

Râh-1 Mevlâ'ya Resûl'e sâlik

[Çünkü Mevla ve Hz. Peygamber yolunda giden Enes bin Malik şöyle buyurmuştur:]

82. Olmamışdı dahı halk arz u semâ

Bulmamıșdı bu cihan neșv ü nemâ

[Yer ve gök henüz yaratılmamış, bu dünya daha ortaya çıkarılmamıştı.]

83. Yoğ idi dahı leyâl ü eyyâm

Yoğ idi dâ'ire-i nazm u nizâm

[Gece ve gündüz henüz yoktu. Dünyanın ölçü ve düzeni daha kurulmamıştı.]

84. Bundan akdem iki bin yıl Yezdân

Rızk-1 mahlûkunu etmişdi beyân

[Allah, ruhların cesetlerine gelmesinden iki bin yıl önce, yarattıklarının rızkını bildirmişti.]

85. İ'tibâr üzre nazar k1l sen de

Etdigin fi'le bak ol şermende

[Sen de bu hadis üzerinde önemle dur, ibret al! Rızık için yaptığın koşuşturmalara bak da utan!]

86. Gel e bu kıssa-i cân-bahşâyı

Bu güzel vâkı'a-i behsâyı 
87. Âyet-i nahnu kasemnâda da bul Zevk-i lafzında vü ma'nâda da bul

[Gel, bu cana can katan kıssanın, bu güzel ve iyiliğe dair olayın ifade ettiği manayl "Biz taksim ettik." âyetinden de çıkar. Söz konusu hadis ile âyetin lafız ve anlamından zevk duy.]

88. Sâ'il-i hikmet olup hâr olma Münkir-i kudret olup zâr olma

[(Allah'ın rızlk konusundaki) hikmetini sorup manen küçük düşme. Allah'ın kudretini inkâr edip sızlanma.]

89. Boynuna lâzım olan emre 'amel

Eyle ey gâfil [o] hengâm-1 ecel

[Ey gafil! Ecel vakti gelmeden önce senin üzerine düşen, (Illahî) emre uygun davranışlarda bulunmaktır.]

90. Kula teslîm ü itâ'at lâzım

Bendeye gerden-i haşyet lâzım

[Kulun Hakk'a teslim olmasl ve itaat etmesi gerekir. Köleye de korku boyunluğu lazımdır.]

91. Bahr-1 gavgâda şinâverliği ko

I'tirâf eyle deyip illâ Hû

[Kavga denizinde yüzmeyi bırak! "Allah'tan başka ilah yok” deyip hata ve kusurlarını itiraf et.]

92. Kul hüvallâhu Ahad nass eyler Vahdet-i ${ }^{8}$ zâtını muhtass eyler

“De ki: O Allah'tır, tektir." âyeti kesin bir şekilde zatın birliğini Hakk'a ait gösterir.

93. Öyle bir pâdişeh-i Kâdir'dir 'Azamet sâhibidir Zâhir'dir

[Allah, her şeye gücü yeten eşsiz bir sultandır. Ululuk sahibidir. Görünendir.]

94. Şâh iken bir kesi eyler bende Bendeyi pâdişeh-i zîbende [Bir kişiyi padişah iken köle, köleyi de görkemli bir padişah yapar.]

\footnotetext{
${ }^{8}$ Yazma nüshada "Vahdeti” şeklinde kayıtlıdır.
} 
95. Kimini 'ilm ile mümtâz etmiş Kimini mîr-i ser-efrâz etmiş

[Kimi insanı ilim ile seçkin kılmış, kimini de üstün bir komutan yapmıştır.]

96. Zerre hâric değil emrinden anın

Var ise fehmede gör iz'ânın ${ }^{9}$

[Onun emrinden bir zerre dahi hariç değildir. Aklın varsa bu gerçeği anlamaya çalış.]

97. Hân-1 lutfunda sigar ile kibâr

Mütena'im dirilir leyl ü nehâr

[Onun iyilik sofrasında, küçük büyük herkes gece gündüz bolluk içinde yaşar.]

98. Vüs'at-1 süfre-i cûd-1 Mevlâ

Ya'nî meydân-1 kilâr-1 na'mâ

99. Bir tabak denlü değildir hâsıl

Cirm-i dünyâ ana nisbet ey dil

[Ey gönül! Dünyanın hacmi, Mevla'nın cömertlik sofrasının genişliği yani nimetler kilerinin meydanına kıyasla bir tabak kadar bile değildir.]

100. Ebhur-1 rahmetine nisbet ile Kerem ü minnetine nisbet ile

101. Bir içim su değil ey cân-1 peder

Ebhur-1 rûy-1 zemîn ser-tâ-ser

[Ey babasının canı! Yeryüzündeki bütün denizler, Hakk'ın ikramı, iyiliği ve rahmet deryasına kıyasla bir içim su dahi değildir.]

102. Kibriyâsında bu denlü eşyâ

Emkine ezmine yek-pâre fenâ

[Onun büyüklüğü karşısında zaman, mekân ve varlıkların tamamı yok sayılır.]

103. Ceberûtunda müzellât olmuş

Melekûtunda iki kat olmuş

[(Varlıklar,) Allah'ın ceberutunda zelil, melekûtunda ise iki kat olmuştur.]

104. Pençe-i kudret ile zabt etmiş

Habl-i vüskâ ile key rabt etmiş

[(Allah, varlıkları) ne vakit kudret pençesiyle idaresi altına almış ve sağlam halatla bağlamış?]

\footnotetext{
${ }^{9}$ Yazma nüshada “iz’ânıñ” derkenarda, “îkânıñ”” metinde yazılmıştır.
} 
105. Cümle 'âlem o serây-1 kudret

Cümle dünyâ 'ucezâ-yı hikmet

[Bütün âlem o kudretin bir sarayıdır. Tüm dünya hikmetini anlamaktan aciz kalmıştır.]

106. Yok bu vâdîde hele medhal-i 'akl

Cereyân eyleyemez faysal-1 'akl

[Bu alanda özellikle aklın dâhil olacağı bir konu yoktur. Aklın kesin hükümleri burada geçmez.]

107. 'Ukalâ bunda piyâde yürüdi

G1ll u gișdan hele sâde yürüdi

[Akıllılar bu yolda yaya kaldı. Kin ve hileden uzak/temiz bir şekilde yürüdü.]

108. Gayriden eyle hemân nefy-i İlâh

De ki ellâ na 'bude illallâh

[Allah'tan gayrısını hemen başka yere sür ve de ki: “Allah'tan başkasına ibadet etmeyin."]

109. Sana temhîd ise etdik bu kadar

İstikâmetle çalış çekme keder

[Senin için gerekli öğ̈̈tleri bu kadar dile getirdik. Bundan sonra doğrulukla çalış ve üzülme.]

110. Yâ İlâhî bana ihsân eyle

Nâ'il-i matlab-1 gufrân eyle

[Ey Allah'ım! Bana ihsanda bulun. Merhametinle isteklerime kavuştur.]

111. Vâlid ü vâlidemi şâd eyle

Dûzah u hevlden âzâd eyle

[Annemi ve babamı sevindir. Onları cehennem ve diğer korkulardan kurtar.]

112. Eyle meskenlerini dâr-1 na'îm

Eyleme kahrın ile nâr-1 cahîm

[Yerlerini cennet eyle, gazabınla cehennem ateşi yapma.]

113. Hürmet-i hazret-i sultân-1 enâm

Hürmet-i hazret-i ashâb-1 kirâm

[Kâinatın sultanı Hz. Muhammed ve onun sahabeleri hürmetine...]

114. 'Arş u kürs ü keremin hürmetine

Rûh-1 levh ü kalemin hürmetine

[Arş, kürsü ve cömertliğinin hürmetine... Kalem ve levhanın ruhu hürmetine...]

115. Hürmet-i hazret-i Kur'ân-1 Kerîm

Ey kerem kânı eyâ cûdu 'amîm

[Yüce kitabımız Kur'ân-ı Kerim hürmetine... Ey bağış kaynă̆ı! Ey cömertliği umumi olan!] 
116. Hâlet-i nez'imi âsân eyle

Yerimi ravza-i rızvân eyle

[Ölüm anımı, can çekişimi kolaylaştır. Yerimi cennet bahçelerinden bir bahçe eyle.]

117. Zihnî̀-i gam-keşi nâlân etme

Hevl-i nîrân ile giryân etme

[Gam çeken Zihnî'yi inletme, cehennem korkusu ile ăglatma!]

118. Eyle ser-rişte-i 'avf u gufrân

İşbu tuhfem benim ey zi'l-ihsân

[Ey ihsan sahibi (Rabbim)! Sana hediyem bu mesnevidir. Beni, af ve merhamet ettiklerinin arasinda eyle.]

\section{KAYNAKÇA}

AYDIN, Fuat (2004). "Melekût”, TDVIA, 29, s. 45-47.

ÇELEBİOĞLU, Amil (1998). Eski Türk Edebiyatı Araştırmaları, İstanbul: Milli Eğitim Bakanlığı Yayınları.

DERMAN, M. Uğur ve Mustafa UZUN (1992). "Besmele (Hat)”, TDVİA, 5, s. 532537.

DURAN, Hamiye (2014). Besmele Tefsiri (Şerh-i Besmele) Hünkâr Hacı Bektâş-ı Velî, Ankara: Türkiye Diyanet Vakfı Yayınları.

EFE, Ahmet (2014). Besmele Yazıları, Ankara: Akçağ Yayınları.

GÖZÜBÜYÜKZADE, İbrahim Efendi (1977). Risâletün fî Hakk-il Besmele (Besmele Risalesi), Ankara: Sevinç Matbaası.

GÜNDÜZ, İrfan (1993). “Ceberût”, TDVİA, 7, s.193-194.

GÜRGENDERELİ, Müberra (2010). Türkçe Mesnevilerde Besmele Şiirleri, İstanbul: Acar Bilgi Merkezi Yayınları.

KARTAL, Ahmet (2013). Doğu’nun Uzun Hikâyesi Türk Edebiyatında Mesnevî, İstanbul: Doğu Kütüphanesi Yayınlar1.

MACİT, Muhsin (2001). Erzurumlu Zihnî Divanı, Ankara: Kültür Bakanlığı Yayınları. 
SEVGİ, Ahmet (1999). "Molla Câmî’nin Besmele Şerhi ve Türk Edebiyatına Tesirleri”, S.Ü. Türkiyat Araştırmaları Dergisi, 5, s. 1-50.

TULUM, Mertol (2011). 17. Yüzyıl Türkçesi ve Söz Varlı̆̆l, Ankara: Türk Dil Kurumu Yayınları.

UZUN, Mustafa (1992). “Besmele (Kültür ve Edebiyat)”, TDVİA, 5, s. 538-540.

ÜSTÜNER, Kaplan (2014). Tasavvuf ve Klasik Şiirimiz, Ankara: Akçağ Yayınları.

ÜZGÖR, Tahir (1990). Türkçe Divan Dibaceleri, Ankara: Kültür Bakanlığı Yayınları.

YAVUZ, Yusuf Şevki (2003). "Levh-i Mahfûz”, TDVİA, 27, s. 151.

YILDIRIM, Suat (1992). "Besmele”, TDVIAA, 5, s. 529-532. 